\title{
Generations X and Y Attitude towards Controversial Advertising
}

\author{
Hiram Ting \\ Universiti Malaysia Sarawak \\ Ernest Cyril de Run \\ Universiti Malaysia Sarawak
}

\begin{abstract}
Segmentation has been useful in advertising decisions and subsequently the generation approach has emerged as a superior segmentation approach. The purpose of this article is to examine the attitudes of generation $\mathrm{X}$ and generation $\mathrm{Y}$ towards controversial advertising. Structured questionnaires were distributed throughout Malaysia, and a total of 768 usable questionnaires were obtained. Findings show that the two generational cohorts are significantly different in attitude towards controversial advertising. Generation $\mathrm{X}$ found the advertising of female contraceptives, feminine hygiene products, and funeral services to be more controversial, whereas generation $\mathrm{Y}$ found the advertising of alcoholic products, condoms, and gambling to be more of a controversy. In terms of the reasons of controversy, generation $\mathrm{X}$ found only health and safety issues to be more controversial whereas generation Y, hard sell, nudity, racist images, sexist images, and subject too personal. Future studies are therefore needed to validate the segregation of generations in Malaysia to secure effective marketing strategy.
\end{abstract}

Keywords: Generation X, Generation Y, Controversial advertising, Malaysia

\section{Introduction}

Marketing practitioners are continually confronted with the intricate task of advertising products/services to increasing diversified consumers in the marketplace. Hence it is paramount that the advertising communicates with the targeted ones effectively in order to yield favorable responses continually (Wells et al., 2003). This is why market segmentation has been used extensively in advertising decisions (Kamakura and Wedel, 1995; Kaynak and Kara, 1996). The underlying principle is to target groups of consumers with homogeneous bonds since they are more likely to be identical in their response to advertising (Schewe and Meredith, 2004). 
Although several segmentation strategies such as those based on demographic, geographic, and psychographic variables have been used (Kotler and Armstrong, 2011), an innovative and highly successful segmentation approach utilizing generational cohort, notably the Veterans, Baby-boomers, generation $\mathrm{X}$ and generation $\mathrm{Y}$, organized by their respective birth years, is gradually being recognized (Meredith and Schewe, 2002). Even though generation cohorts may be viewed as just another useful demographic variable to create groups and describe segments, it actually goes beyond to unveil segment motivation. Generation cohorts also unveil values and lifestyle characteristics such as that of psychographics, but has superior tracking and forecasting ability due to its lifelong effect (Schewe and Meredith, 2004).

The purpose of this study is to examine the attitudes of Malaysians towards controversial advertising based on two generational cohorts, namely generation $\mathrm{X}$, who is born between 1961 and 1980, and generation Y, who is born between 1981 and 2000. It is postulated that people from the same cohorts, regardless of the change in life stages, will have similar attitudinal patterns towards the said advertising, thus extending the understanding of consumers and enhancing the predictability of their future responses. The relationship between cohorts will provide additional clarification to the past knowledge on consumer behaviour. The implication of generational cohort in the Malaysian context will also be elucidated.

\section{Literature Review}

\section{Generational Cohort}

Generational cohorts are groups of people who are born during the same time period, and go through similar experiences of external events. These shared experiences affect their beliefs, attitudes and purchasing behavior in ways that remain with them over their entire lifetime (Ryder, 1965; Meredith and Schewe, 1994). Such segmentation is particularly useful because it provides a long standing solution to understanding consumers. As cohorts age and enter into new life stages, they will bring along their value systems, needs and wants with them (Holbrook and Schindler, 1989; Schuman and Scott, 1989; Hauck and Stanforth, 2007).

The concept of generational cohort has been discussed widely in many disciplines, including business (Mannheim, 1952; Rodgers, 1982; Mason and Fienberg, 1985; Rogler, 2002; Glenn, 2005). A good amount of studies have been done on linking work value to generational differences (Smola and Sutton, 2002; Cennamo and Gardner, 2008; Chen and Choi, 2008; Gursoy et al., 2008). Many have concluded that such differences, especially in work values and expectations, are surreal between different cohorts in workforce (Yu and Miller, 2003; Cennamo and Gardner, 2008; D'Amato and Herzfeldt, 2008). Moreover, knowledge regarding to generational differences can help organizations predict the degree of receptivity and resistance of their workforce to planned corporate change and enhance the development of effective work relationships and organizational effectiveness (Jurkiewicz and Brown, 1998; Kupperschmidt, 2000). 
Research has shown the potential of generational cohort in developing segmentation profile and implementing marketing strategies (Reynolds and Rentz, 1981; Meredith and Schewe, 1994; Schewe and Noble, 2000; Noble and Schewe, 2003). Generational labels such as leading-edge boomers, trailing-edge boomers and generation Xers are generally associated with marketing activities (Schewe and Noble, 2000; Noble and Schewe, 2003). It is considered as a basis for marketing practitioners to segment the consumers (Mittal et al., 2008). For example, understanding cohorts is useful in developing marketing communication campaigns. Music, movie stars or icons that cohorts identified with from their coming-of-age years can be an effective means of directing communication messages to a given cohort (Noble and Schewe, 2003).

This study adapts two generation labels designated by Zemke et al. (2000): generation $\mathrm{X}$ and generation $\mathrm{Y}$. The former is consisted of individuals born between 1961 and 1980, and the latter, who is also called Nexters or the Millennials, was born between 1981 and 2000 (Arsenault, 2003). Generation X is said to be born during the time of political and social instability (Moore and Carpenter, 2008). Hence they become skeptical about their future, and as a result they learn to survive, and are highly individualistic (Howe and Strauss, 1993). They are even entrepreneurial risk taker (de Meuse et al., 2001). Moreover they tend to put personal freedom and challenging work ahead of job security and status (Kupperschmidt, 2000; Schewe and Meredith, 2004). Generation Y, in turn, tends to be very positive about their future because of economic and technological developments, especially in the advent of the internet (Boulds, 2000; Smola and Sutton, 2002; Schewe and Meredith, 2004). They witness the increase of diversity including ethnic, linguistic, non-traditional families, and dramatic change of media (Paul, 2001). Furthermore they tend to be uncertain spenders, having little brand loyalty and short-term wants (Pendergast, 2009), It is believed that all these characteristics of the two cohorts will help articulate attitude of Malaysians towards controversial advertising.

\section{Controversial Advertising}

Given the dynamism of the contemporary setting, managers and marketing practitioners have been employing fresh and creative methods in advertising in order to gain awareness, interest and desired response from the consumers (Jewler and Drewniany, 2001). As a result, images, slogans and themes which are potentially controversial are used and exploited (Waller, 1999; McIntyre, 2000; Waller, 2004). Due to its probable usefulness coupled with the rapid development in media, such exploitation has become increasingly common over the last three decades (Severn et al., 1990; Pope et al., 2004). However, it is also palpable that it can cause negative reactions or offence, and result in actions like negative publicity, receiving complaints, falling sales, and even product boycott (Fam and Waller, 2003). In spite of the concerns, marketing practitioners nowadays continue to seize every opportunity to draw attention boldly (Fogul, 2002).

Accordingly, many academic researchers began to investigate consumer attitudes towards controversial advertising based on different factors, such as gender, religion, and culture (Ricks, 1983; Luqmani et al., 1987; Root, 1987; Terpstra, 1987; Cateora, 1990; Michell and Al-Mossawi, 1999; Phau and Prendergast, 2001; Prendergast et al., 2002; Waller et al., 2005; Fam et al., 2009). Descriptions like “unmentionables", 
"offensive, intrusive, and irritating advertising", "socially sensitive products", "decent products", "acceptable advertising” and "advertising ethics" were used to understand the subject matter (Bartos, 1981; Wilson and West, 1981; Aaker and Bruzzone, 1985; Rehman and Brooks, 1987; Triff et al., 1987; Shao and Hill, 1994; Fahy et al., 1995; Waller, 1999; Phau and Prendergast, 2001; Li et al., 2002). Due to the prevalent use of controversial advertising with no sign of abatement, similar studies are also performed in Malaysia in recent years (Waller and Fam, 2000; Waller et al., 2005; Munusamy and Wong, 2007; de Run et al., 2010).

\section{Controversial Products and Reasons}

Two different aspects to controversial advertising, namely products and reasons or executions, are identified in past studies (Barnes and Dotson, 1990). In the same way, "the matter" (goods, services or ideas being advertised), and "the manner" (advertising executions) of the advertising are also investigated (Phau and Prendergast, 2001). To date researchers have come out with a list of 17 controversial products and 12 reasons (Waller and Fam, 2000; Waller et al., 2005; de Run et al., 2010). These products and reasons are adopted in this study. With alphabetical order, the products are alcohol, charities, cigarettes, condoms, female contraceptives, female hygiene products, female underwear, funeral services, gambling, guns and armaments, male underwear, pharmaceuticals, political parties, racially extremist groups, religious denominations, sexual diseases (AIDS, STD prevention), and weight loss programs. The reasons, in turn, are anti-social behavior, concern for children, hard sell, health and safety issues, indecent language, nudity, racist images, sexist images, stereotyping of people, subject too personal, violence and Western images.

The literatures aforementioned have shown the clear differences between the older generation as in generation $\mathrm{X}$ and the younger generation as in generation $\mathrm{Y}$. Therefore it is inferred that there are differences in their attitude towards the two components of controversial advertising in its product and reason. Accordingly two hypotheses are formulated in this study for subsequent analysis. First, there is difference between generation $\mathrm{X}$ and generation $\mathrm{Y}$ for what is controversial, hence the following hypothesis:

$\mathrm{H}_{1}$ : Generation $\mathrm{X}$ would find controversial advertising of products more controversial than Generation Y.

Secondly, there is difference between generation $\mathrm{X}$ and generation $\mathrm{Y}$ for why it is controversial, hence the following hypothesis:

$\mathrm{H}_{2}$ : Generation $\mathrm{X}$ would find the reasons of controversy more controversial than Generation Y.

\section{Methodology}

In order to investigate the products and the reasons that are controversial for Malaysians when advertised, a structured-questionnaire was designed based on previous studies (Shao and Hill, 1994; Waller et al., 2005; de Run et al., 2010). 
Purposive and snowball sampling strategies were used as only respondents who were born between 1961 and 2000 were sampled. They are the generation X and generation $\mathrm{Y}$ in Malaysia, and are now between 11 and 30 years old, and between 31 and 50 years old respectively (Zemke et al., 2000). Questionnaire was distributed throughout Malaysia, and a total of 768 usable questionnaires were obtained and computed.

The questionnaire was part of a larger study but only sections related to this paper are discussed here. Part A contained questions on demographics. Part B contained a list of 17 products and Part C 12 reasons for respondents to determine levels of controversy. A five-point Likert type format where $1=$ not at all controversial to $5=$ extremely controversial was used. Data were analyzed using descriptive analysis and t-test.

\section{Findings}

Table 1 depicts a summation of respondents' demographic information. Age is used to indicate which cohorts the respondents belong to. Mean scores for controversy of the advertising in the components of the products and the reason is shown in Table 2.

Table 1: Respondent Demographics

\begin{tabular}{llcc}
\hline & Variable & Frequency & Percent \\
\hline Gender & Male & 365 & 47.5 \\
& Female & 403 & 52.5 \\
\hline Age cohort & Generation Y $(11-30)$ & 505 & 65.8 \\
& Generation X $(31-50)$ & 263 & 34.2 \\
Religion & Muslim & 445 & 57.9 \\
& Buddhist & 166 & 21.6 \\
& Christian & 136 & 17.7 \\
& Hindu & 9 & 1.2 \\
\hline
\end{tabular}

Findings of the t-test analysis based on the two generational cohorts are also incorporated into Table 2. For controversial products, there was statistically difference between the two cohorts on alcoholic products, condoms, female contraceptives, feminine hygiene products, funeral services, gambling, and pharmaceuticals. Comparatively, generation $\mathrm{X}$ found the advertising of female contraceptives, feminine hygiene products, funeral services, and pharmaceuticals to be more controversial, whereas generation $\mathrm{Y}$ found the advertising of alcoholic products, condoms, and gambling to be more of a controversy.

Hence the testing of the first hypothesis was found to be partially acceptable as not all the products tested were seen as more controversial by generation $\mathrm{X}$ over that of generation Y. Seven products were found to be significantly different between generations but only four were seen as more controversial by generation $\mathrm{X}$. 
Table 2: Means \& t-test for Controversial Advertising by Generational Cohort

\begin{tabular}{lllllll}
\hline \multirow{2}{*}{ Variables } & \multicolumn{2}{c}{ Overall } & \multicolumn{2}{c}{ Gen Y } & \multicolumn{2}{c}{ Gen X } \\
\cline { 2 - 7 } & Mean & S. D & Mean & S. D & Mean & S. D \\
\hline Alcoholic products** & 3.48 & 1.48 & 3.60 & 1.45 & 3.24 & 1.53 \\
\hline Charities/Fund raising & 2.22 & 1.00 & 2.18 & 1.05 & 2.31 & 0.89 \\
\hline Cigarettes/tobacco & 3.19 & 1.27 & 3.22 & 1.30 & 3.14 & 1.23 \\
\hline Condoms** & 3.38 & 1.29 & 3.50 & 1.28 & 3.14 & 1.26 \\
Female Contraceptives* & 3.33 & 1.37 & 3.25 & 1.36 & 3.50 & 1.38 \\
\hline Female Underwear & 3.30 & 1.32 & 3.30 & 1.36 & 3.29 & 1.23 \\
\hline Feminine Hygiene Products** & 3.17 & 1.24 & 3.08 & 1.30 & 3.33 & 1.12 \\
\hline Funeral Services** & 3.01 & 1.52 & 2.78 & 1.50 & 3.45 & 1.46 \\
\hline Gambling** & 3.34 & 1.27 & 3.44 & 1.32 & 3.14 & 1.13 \\
\hline Guns \& Armaments & 2.97 & 1.34 & 2.91 & 1.40 & 3.08 & 1.20 \\
Male Underwear & 3.24 & 1.36 & 3.22 & 1.39 & 3.27 & 1.31 \\
\hline Pharmaceuticals** & 2.45 & 1.46 & 2.29 & 1.43 & 2.76 & 1.46 \\
\hline Political Parties & 2.58 & 1.36 & 2.54 & 1.34 & 2.66 & 1.39 \\
\hline Racially Extremist Groups & 3.41 & 1.32 & 3.34 & 1.38 & 3.52 & 1.20 \\
Religious Denominations & 2.99 & 1.22 & 2.96 & 1.28 & 3.03 & 1.08 \\
\hline Sexual Diseases & 3.05 & 1.41 & 3.06 & 1.47 & 3.05 & 1.29 \\
\hline Weight Loss Programs & 2.38 & 1.19 & 2.35 & 1.27 & 2.42 & 1.04 \\
\hline
\end{tabular}

* t-test significant at .05, ** t-test significant at .00

In terms of reasons for being controversial, there was statistically difference on concern for children, hard sell, health and safety issues, indecent language, nudity, racist images, sexist images, and subject too personal. Comparatively, generation $\mathrm{X}$ found just health and safety issues to be more controversial, whereas Generation $\mathrm{Y}$ found concern for children, hard sell, nudity, indecent language, racist and sexist images, and subject too personal to be more controversial. Findings of the t-test analysis by generational cohort are also incorporated into Table 3.

Hence the testing of the second hypothesis was found to be partially acceptable as not all the reasons tested were seen as more controversial by generation $\mathrm{X}$ over that of generation Y. Eight reasons were found to be significantly different between generations but only one was seen as more controversial by generation $\mathrm{X}$. 
Table 3: Means \& t-test for reasons for Controversy by Generational Cohort

\begin{tabular}{lcccccc}
\hline \multirow{2}{*}{\multicolumn{1}{c}{ Variable }} & \multicolumn{2}{c}{ Overall } & \multicolumn{2}{c}{ Gen Y } & \multicolumn{2}{c}{ Gen X } \\
\cline { 2 - 7 } & Mean & S. D & Mean & S. D & Mean & S. D \\
\hline Anti-social Behaviour & 2.94 & 1.25 & 2.92 & 1.28 & 2.97 & 1.19 \\
\hline Concern for Children* & 2.75 & 1.34 & 2.83 & 1.35 & 2.60 & 1.29 \\
\hline Hard Sell* & 3.23 & 1.25 & 3.30 & 1.29 & 3.10 & 1.16 \\
\hline Health \& Safety Issues** & 2.90 & 1.35 & 2.71 & 1.34 & 3.29 & 1.27 \\
Indecent Language** & 3.13 & 1.24 & 3.33 & 1.30 & 2.75 & 1.01 \\
\hline Nudity** & 3.50 & 1.35 & 3.70 & 1.34 & 3.11 & 1.27 \\
\hline Racist Images* & 3.23 & 1.32 & 3.31 & 1.36 & 3.06 & 1.24 \\
\hline Sexist Images** & 3.35 & 1.23 & 3.46 & 1.25 & 3.16 & 1.16 \\
\hline Stereotyping of People & 3.08 & 1.26 & 3.14 & 1.31 & 2.97 & 1.16 \\
\hline Subject too Personal** & 3.32 & 1.22 & 3.41 & 1.21 & 3.14 & 1.21 \\
Violence & 3.37 & 1.25 & 3.43 & 1.26 & 3.27 & 1.22 \\
\hline Western Images & 3.37 & 1.29 & 3.42 & 1.30 & 3.26 & 1.27 \\
\hline * t-test significant at .05, ** t-test significant at 00 & & & \\
\hline
\end{tabular}

$*$ t-test significant at .05, ** t-test significant at .00

\section{Discussions}

The results indicate a very appealing outlook on how generation shapes and affects the attitudes towards controversial advertising in its bare component of the products and the reasons. First, it must be said that Malaysians can indeed be segmented into different generational cohorts because their dissimilarities are shown in their attitudes towards controversial advertising. This validates the past studies on the implication of generational cohort in marketing in various countries. (Excousseau, 2000; Meredith and Schewe, 2002; Schewe and Meredith, 2004; Hung et al., 2007; Motta and Schewe, 2008). This also highlights the fact that using cohort as a basis to segment the consumers is useful in developing goods and services because they can be more aligned with the consumers' needs and wants (Mittal et al., 2008).

From the testing of hypothesis it appears that generation $\mathrm{Y}$ is sensitive towards the advertising of controversial products and has shown stronger sensitivity to a variety of reasons as to why the advertising of products are controversial. Both hypotheses are only partially accepted, and this indicates that while the older generation has different views as to what is controversial, the younger generation has developed its own strong views.

Female contraceptive and hygiene products are found controversial in both generations $\mathrm{X}$ and $\mathrm{Y}$ because these products are still perceived as something sensitive and secretive today. Additionally, religion must have played an important role because Muslims, along with other religious groups, continue to uphold modesty in their teachings (de Run et al., 2010). Specifically, the advertising of these two products is found to be more controversial in generation $\mathrm{X}$ because the level of exposure to them in 1970s was very minimal. Communicational and digital technologies were not in place in many parts of Malaysia during those times. 
Moreover, middle-aged Malaysians today are more cautious or skeptical in their characteristics due to their social upbringing.

Funeral services, in turn, always maintain as a grave matter to all Malaysians (Waller and Fam, 2000). This explains why the older ones in generation $X$ found it controversial. However the findings in relation to generation $\mathrm{Y}$ may infer something different. Younger generation is becoming less interested and bound by family's tradition, superstition and culture as diversity in ethnics and non-traditional families continues to grow. They could even see the advertising of funeral service as a good thing because it facilitates awareness and adoption process.

Interestingly, in spite of the fact that the advertising of alcoholic products, condoms, and gambling is becoming more apparent as a result of the advancement of media, generations $\mathrm{X}$ and $\mathrm{Y}$ still consider them controversial, with the younger ones finding them to be more controversial. This is most likely because Muslims, who make up the highest percentage of religious group in the population of Malaysia, recognize Sharia laws, and the general public are becoming more and more aware of the regulations enforced by Malaysian government to safeguard these advertisements (Waller and Fam, 2000; de Run et al., 2010). Another noteworthy finding is that both cohorts found racially extremist group to be controversial. This supports the findings of Waller (2005), and Fam and Waller (2003) in their respective cross-cultural studies. Since Malaysia is a multi-racial and cultural country, Malaysians have relatively learnt, through past experiences and education, the importance of maintaining harmony between races.

As far as the reasons for being controversial are concerned, the findings show a very one-sided phenomenon in generation $\mathrm{Y}$, which nearly defeats the second hypothesis. Generation $\mathrm{X}$ found only health and safety issues to be more controversial but generation $\mathrm{Y}$ found concern for children, hard sell, indecent language, nudity, racist and sexist images, and subject too personal to be more controversial. As expected, living through the period of instability, most remarkably the times of social insecurity, where discrepancies between races and opportunities were often the issues at hand, have caused generation $\mathrm{X}$ to be more individualistic and cautious in their lives and works. Although they also found hard sell, nudity, subject too personal, racist and sexist images to be controversial based on the means scores, the responses are not as strong as that of generation Y.

For generation Y, despite the rapid development in media, especially the internet, it is apparent that the regulations on the contents and executions in advertisement stipulated by the governing bodies, such as the Advertising Code in Malaysia are still prevailing (Deng et al., 1994). Although younger generation may be more receptive to incessant exposure from various advertisements, they are still aware of the potential negativity that these executions may generate in an increasing diverse community. The findings commensurate with the study conducted by Fam and Waller (2003) where Malaysians with the average age of 21 perceived racist and sexist images, and nudity as the top three reasons of controversy. Lastly, the controversies instigated by indecent language, hard sell and subject too personal imply that the younger generation is becoming more collective in their behavior. 
It is necessary to take note again that seeing the advertising controversial is not necessary a bad thing. Marketing practitioners can continue promote their controversial but lawful products in such a way that it generates consumers' interest and minimizes distrust. At the same time, consumers may become more aware of and familiar with a certain products due to its controversial element. When considering the characteristics of generation $\mathrm{Y}$, such as uncertain in what they want and spend, and highly exposed to media, this may provide another viewpoint as to why the younger generation found a good number of products and reasons to be more controversial than the older generation. From the managerial standpoint, this demonstrates the potential in utilizing controversial advertising to capture generation $\mathrm{Y}$, but it also discloses the complexity in grasping the needs and wants of the younger ones. For example, a young non-Muslim may find the advertising of alcoholic products to be controversial and the use of indecent language as a cause of controversy because he knows what are the norms and regulations in the community that he lives in. Nevertheless it does not mean he has not consumed beer and sworn at others, and will not perform these behaviors in the future. Neither does it mean he has been offended and would not have favorable behavior towards the product. On the contrary, the perceived controversy may become subject of a talk, and end up having more people interested in the advertisement and the product. Studies have shown that advertising can even be something entertaining (Pollay and Mittal, 1993; Korgaonkar et al., 2001), and it may be the case with generation $\mathrm{Y}$ when viewing controversial advertising. Generation $\mathrm{Y}$ does not inherit everything from generation X, nor are they becoming more conventional due to their sensitivity towards controversial advertising, particularly the reasons of controversy. It just shows the unpredictability and intricate change of attitudes in generation $\mathrm{Y}$ or the younger ones today.

Overall, the findings reveal that the reason for being controversial is a stronger indicator of controversy than the product itself. In other words consumers are generally more concerned with the execution of the advertisement than the matter or the product itself (Prendergast et al., 2002). While generation $\mathrm{X}$ views the products to be generally more controversial, generation $\mathrm{Y}$ considers the reasons to be more of a controversy. This further shows the complexity in the younger ones.

\section{Conclusion}

It is essential at the foremost to identify the products that are controversial to different groups of people. It is equally important to know the reasons for being controversial so that the execution of the advertisements can be fittingly implemented. Notwithstanding its usefulness in capturing attention, Dahl et al. (2003) pointed out that controversial advertising can turn into offensive when it becomes something that violates the norm of the society. Therefore marketing practitioners have to know the perception of the public towards their products, identify their targeted segment, and execute the advertisements wisely to secure desired results, thus preventing unwanted outcomes.

This study validates the magnitude of understanding generational cohorts in order to make the products effectively appealing to the consumers through meticulous design of the products and advertising executions. On the whole it exemplifies the use of cohort in generations $\mathrm{X}$ and $\mathrm{Y}$ in the Malaysian context to identify the different 
attitudes that they have towards controversial advertising. Moreover it indicates a significant change of attitude in generation $\mathrm{Y}$ towards the level of controversy between the products and the reasons. It is therefore surmised that recognizing the homogeneity within cohorts and the heterogeneity between cohorts can enhance the understanding of consumers and the subsequent segmentation strategy. It can also allow better forecasting of future responses of the consumers from the same generational cohorts (Schewe and Meredith, 2004).

It is believed that future research should be conducted to validate the segregation of generational cohorts in Malaysia because labels such as generations $\mathrm{X}$ and $\mathrm{Y}$ are borrowed from that of the West. The forming of these cohorts and the relationships between cohorts can thus be further explored and investigated to underpin the understanding of the Malaysian consumers and the implementation of segmentation and marketing mix. Moreover generation study can be applied on specific controversial or non-controversial advertisements in order to examine consumers' attitude towards specific products. Furthermore, since Malaysia is a country endowed with diversity of races, a cross racial and cultural study can be done to gain more insights on the implication of race, religion and cultural values on the formation of generational cohort.

\section{Acknowledgement}

This paper is based on research at Universiti Malaysia Sarawak (UNIMAS) under Geran Dana Principal Investigator (Grant no: 03/DPI07/823/2011 (07)). The authors express their gratitude to UNIMAS.

\section{References}

Aaker, D. A. and D. E. Bruzzone (1985). "Causes of Irritation in Advertising." Journal of Advertising 49: 47-57.

Arsenault, P. M. (2003). Leadership Assessment and Development: Recommendations for A New Assessment Model. Improving Leadership in Nonprofit Organizations. R. Riggio and S. Smith-Orr. San Francisco, CA, Jossey-Bass: 250-264.

Barnes, J. H. and M. J. Dotson (1990). "An Exploratory Investigation into the Nature of Offensive Television Advertising." Journal of Advertising 19(3): 61-69.

Bartos, R. (1981). "Ads that Irritate May Erode Trust in Advertised Brands." Harvard Business Review: 138-139.

Boulds, E. M. (2000). Praying that Receives Answers. New York, NY, Whitaker House.

Cateora, P. R. (1990). International Marketing. Homewood, Richard D. Irwin, Inc.

Cennamo, L. and D. Gardner (2008). "Generational Differences in Work Values, Outcomes and Person-Organization Value Fit." Journal of Managerial Psychology 23: 891-906.

Chen, P. J. and Y. Choi (2008). "Generational Differences in Work Values: A Study of Hospitality Management." International Journal of Contemporary Hospitality Management 20(6): 595-615. 
D’Amato, A. and R. Herzfeldt (2008). "Learning Orientation, Organizational Commitment and Talent Retention across Generation." Journal of Managerial Psychology 23(8): 925-953.

Dahl, D. W., K. D. Frankenberger, et al. (2003). "Does It Pay to Shock? Reactions to Shocking and Non-shocking Advertising Content among University Students." Journal of Advertising Research 43(3): 268-280.

de Meuse, K. P., T. J. Bergmann, et al. (2001). "An investigation of the relational component of the psychological contract across time, generation, and employment status." Journal of Managerial Issues 13(1): 102-118.

de Run, E. C., M. M. Butt, et al. (2010). "Attitudes towards Offensive Advertising: Malaysian Muslims' Views." Journal of Islamic Marketing 1(1): 25-36.

Deng, S., S. Jivan, et al. (1994). "Advertising in Malaysia: A Cultural Perspective." International Journal of Advertising 14(3): 231-243.

Excousseau, J. L. (2000). La mosaique des ge'ne'rations: comprendre les sensibilite's et les habitudes des Franc, ais. Paris, E' ditions d'Organisation.

Fahy, J., D. Smart, et al. (1995). "Advertising Sensitive Products." International Journal of Advertising 14(231-243).

Fam, K.-S. and D. S. Waller (2003). "Advertising Controversial Products in the Asia Pacific: What Makes Them Offensive?" Journal of Business Ethics 48: 237-250.

Fam, K.-S., D. S. Waller, et al. (2009). "Addressing the Advertising of Controversial Products in China: An Empirical Approach." Journal of Business Ethics 88(1): 43-58.

Fogul, P. (2002). "The Fine Line between Edgy and Offensive Advertising." Retrieved 23 March, 2012, from www.ihaveanidea.org/articles/entries/00000038.htm.

Glenn, N. D. (2005). Cohort Analysis. Thousand Oaks, CA, Sage Publications.

Gursoy, D., T. A. Maier, et al. (2008). "Generational Differences: An Examination of Work Values and Generational Gaps in the Hospitality Workforce." International Journal of Hospitality Management 27: 448-458.

Hauck, W. E. and N. Stanforth (2007). "Cohort Perception of Luxury Goods and Services." Journal of Fashion Marketing and Management 11(2): 175-188.

Holbrook, M. B. and R. M. Schindler (1989). "Some Exploratory Findings on the Development of Musical Tastes." Journal of Consumer Research 16 (1): 119-124.

Howe, N. and B. Strauss (1993). 13th Gen: Abort, Retry, Ignore, Fail? New York, NY, Vintage Books.

Hung, K. H., F. F. Gu, et al. (2007). "A Social Institutional Approach to Identifying Generation Cohorts in China with A Comparison with American Customers." Journal of International Business Studies 38: 836-853. 
Jewler, A. J. and B. L. Drewniany (2001). Creative Strategy in Advertising. Belmont, CA, Wadsworth/Thomas Learning.

Jurkiewicz, C. L. and R. G. Brown (1998). "Gen Xers vs. Boomers vs. Matures." Rev. Public Personnel Administration 18(4): 18-37.

Kamakura, W. A. and M. Wedel (1995). "Life-style Segmentation with Tailored Interviewing." Journal of Marketing Research 32(3): 308-321.

Kaynak, E. and A. Kara (1996). Consumer Life-style and Ethnocentrism: A Comparative Study in Kyrgyzstan and Azarbaijan. 49th Esomar Congress Proceedings, Istanbul.

Korgaonkar, P. K., R. Silverblatt, et al. (2001). "Web Advertising and Hispanics." Journal of Consumer Marketing 18(2): 134-152.

Kotler, P. and G. Armstrong (2011). Principles of Marketing. Upper Saddle River, NJ, Prentice Hall.

Kupperschmidt, B. R. (2000). "Multigeneration Employees: Strategies for Effective Management." Health Care Manager 19(1): 65-76.

Li, H., S. M. Edwards, et al. (2002). "Measuring the Intrusiveness of Advertisements: Scale Development and Validation." Journal of Advertising 31(2): 37-47.

Luqmani, M., U. Yavas, et al. (1987). "Advertising in Saudi Arabia: Content and Regulation." International Journal of Advertising 6(1): 59-71.

Mannheim, K. (1952). The Problem of Generations. Essays on the Sociology of Knowledge. P. Kecskemeti. London, Routledge and Kegan Paul: 276-320.

Mason, W. M. and S. E. Fienberg (1985). Cohort Analysis in Social Research: Beyond the Identification Problem. New York, Springer Verlag.

McIntyre, P. (2000). Buy Sexual. The Australian Magazine: 26-29.

Meredith, G. and C. D. Schewe (1994). "The Power of Cohorts." American Demographics 16(12): 22-28.

Meredith, G. and C. D. Schewe (2002). Defining Markets, Defining Moments: America's 7 Generational Cohorts, Their Shared Experiences, and Why Businesses Should Care. New York, John Wiley \& Sons.

Michell, P. and M. Al-Mossawi (1999). "Religious Commitment related to Message Contentiousness." International Journal of Advertising 18: 427-443.

Mittal, B., M. Holbrook, et al. (2008). Consumer Behavior, How Humans Think, Feel, and Act in the Marketplace. Cincinnati, OH, Open Mentis Publishing Company.

Moore, M. and J. M. Carpenter (2008). "Intergenerational Perceptions of Market Cues among US Apparel Consumers." Journal of Fashion Marketing and Management 12(3): 323337.

Motta, P. C. and C. Schewe (2008). "Are Marketing Management Decisions Shaped during One's Coming of Age?" Management Decision 46(7): 1096-1110. 
Munusamy, J. and C. H. Wong (2007). "Attitude towards Advertising among Students at Private Higher Learning Institutions in Selangor." Unitar E-journal 3(1): 31-51.

Noble, S. M. and C. D. Schewe (2003). "Cohort Segmentation: An Exploration of Its Validity." Journal of Business Research 56: 979-987.

Paul, P. (2001). "Getting Inside Gen Y." American Demographics 23(9): 42-50.

Pendergast, D. (2009). "Generational Theory and Home Economics: Future Proofing and Profession." Family and Consumer Sciences Research Journal 37(4): 504-522.

Phau, I. and G. Prendergast (2001). "Offensive Advertising: A View from Singapore." Journal of Promotion Management 7(1): 71-90.

Pollay, R. W. and B. Mittal (1993). "Here's the Beef: Factors, Determinants, and Segments in Consumer Criticism of Advertising." Journal of Marketing 57: 99-114.

Pope, N. K., K. E. Voges, et al. (2004). "The Effect Of Provocation In The Form Of Mild Erotica On Attitude To The Ad And Corporate Image." Journal of Advertising 33(1): 69-82.

Prendergast, G., B. Ho, et al. (2002). "A Hong Kong View of Offensive Advertising." Journal of Marketing Communications 8(3): 165-177.

Rehman, S. N. and J. R. Brooks (1987). "Attitudes towards Television Advertising for Controversial Products." Journal of Healthcare Marketing 7: 78-83.

Reynolds, F. D. and J. O. Rentz (1981). "Cohort Analysis: An Aid to Strategic Planning." Journal of Marketing 45(3): 62-70.

Ricks, D. A. (1983). Big Business Blunders: Mistakes in Multinational Marketing. Homewood, Dow Jones-Irwin.

Rodgers, W. L. (1982). "Estimable Functions of Age, Period, and Cohort Effects." American Sociological Review 47(6): 774-787.

Rogler, L. H. (2002). "Historical Generations and Psychology: The Case of the Great Depression and World War II." American Psychologist 57(12): 1013-1023.

Root, F. R. (1987). Entry Strategies for International Markets. Lexington, Lexington Books.

Ryder, N. B. (1965). "The Cohort as a Concept in the Study of Social Change." American Sociological Review 30 843-861.

Schewe, C. D. and G. Meredith (2004). "Segmenting Global Markets by Generational Cohorts: Determining Motivations by Age." Journal of Consumer Behaviour 4(1): 51-63.

Schewe, C. D. and S. M. Noble (2000). "Marketing Segmentation by Cohorts: the Value and Validity of Cohorts in America and Abroad." Journal of Marketing Management 16 (1): 129-142. 
Schuman, H. and J. Scott (1989). "Generations and Collective Memories." American Sociological Review 54(3): 359-381.

Severn, J., G. E. Belch, et al. (1990). "The Effects of Sexual and Non-sexual Advertising Appeals and Information Level on Cognitive Processing and Communication Effectiveness." Journal of Advertising 19(1): 14-22.

Shao, A. T. and J. S. Hill (1994). "Global Television Advertising Restrictions: The Case of Socially Sensitive Products." International Journal of Advertising 13: 347-366.

Smola, K. W. and C. D. Sutton (2002). "Generational Differences: Revisiting Generational Work Values for the New Millennium." Journal of Organizational Behavior 23: 363382.

Terpstra, V. (1987). International Marketing. New York, NY, The Dryden Press.

Triff, M., D. Benningfield, et al. (1987). Advertising Ethics: A Study of Public Attitudes and Perceptions. 1987 Conference of the American Academy of Advertising, Columbia, South Carolina.

Waller, D. S. (1999). "Attitudes towards Offensive Advertising: An Australian Study." Journal of Consumer Marketing 16(3): 288-294.

Waller, D. S. (1999). "'Get Stuffed": Attitudes towards Pizza Hut's Outdoor Advertising Campaign." Journal of Food Product Marketing 5(4): 45-54.

Waller, D. S. (2004). What Factors Make Controversial Advertising Offensive? A Preliminary Study. ANZCA. Sydney.

Waller, D. S. and K.-S. Fam (2000). "Cultural Values and Advertising in Malaysia: Views from the Industry." Asia Pacific Journal of Marketing and Logistics 12(1): 3-16.

Waller, D. S., K.-S. Fam, et al. (2005). "Advertising of Controversial Products: A Crosscultural Study." Journal of Consumer Marketing 22(1): 6-13.

Wells, W., J. Burnett, et al. (2003). Advertising Principles and Practice. Upper Saddle River, NJ, Pearson Hall.

Wilson, A. and C. West (1981). "The Marketing of 'Unmentionables'." Harvard Business Review: 91-102.

Yu, H. C. and P. Miller (2003). "The Generational Gap and Cultural Influence - A Taiwan Empirical Investigation, Cross Cultural Management." 10 3: 23-41.

Zemke, R., C. Raines, et al. (2000). Generations at Work: Managing the Clash of Veterans, Boomers, Xers, and Nexters in Your Workplace. New York, NY, AMACOM. 